\title{
The analysis of spatial and functional modifications of the palace in Krzesimów in Melgiew commune aiming at adaptation of the building to the requirements of a social welfare home
}

\author{
Karol Krupa, Piotr Gleń \\ Faculty of Civil Engineering and Architecture, Lublin University of Technology \\ e-mail:k.krupa@pollub.pl,glen@pollub.pl
}

\begin{abstract}
The palace in Krzesimów was built in the classicist style at the beginning of $19^{\text {th }}$ century. The building is the part of the palace-park complex entered into the register of monuments because of its historical, aesthetical and landscape values. From 1970s, it is the headquarters of a social welfare home. Over the years, this function enforced many changes in the functional layout of the building to adapt it to the needs of people with various types and levels of disability. Despite many minor renovations and modifications, the palace didn't undergo complete overhaul, which would greatly improve the technical condition of the original fabric. This aim of article is to analyse introduced functional changes, which were supposed to facilitate the use of the building by the handicapped, and to consider what actions must be undertaken in order to improve its technical condition. The authors of the paper underline the need to start renovation works on the basis of the archive documentation, as well as conducted survey and research of its current technical condition.
\end{abstract}

Keywords: social welfare home, monument, palace, Krzesimów.

\section{Introduction}

\subsection{Social welfare homes}

According to the act on the social welfare of $12^{\text {th }}$ march 2004 , the term social welfare home designates "social welfare establishment - regional social policy centre, district's centre for the family support, regional social welfare centre, social welfare home, specialist consultancy centre, including family support, support centre and crisis intervention centre" [1]. The aim of such establishments is to support persons in difficult financial and personal situation, who through no fault of their own can't cope with life's challenges [2]. The basic principle of social welfare homes is that their technical conditions and character should fulfil to the most possible extent the needs and capabilities of their residents. They should have cosy, familial character, so that their residents feel comfortable over there [3]. Nowadays social welfare homes are crucial element of the social welfare system. People who use them have often difficulties to be an independent person in the society. They have reduced level of awareness of their actions [4].

The role of an architect in developing the space adapted for the needs of social welfare homes is very important. The design process has to consider the group of its recipients in order to adapt the building for their needs to the maximum possible extent. Results of the surveys concerning the people who live in social welfare homes show that the reason why 
people land in this kind of establishments there doesn't lie in the problem of their mental handicap but rather their environment, bereavement or poverty [5]. That is why it is the designer's responsibility to create a place that would be friendly and possibly closest to real home. Adaptation of historical buildings for this purpose is not new issue. The authors of this paper would like to present the subject and propose the spatial and functional solutions for the adaptation of a $19^{\text {th }}$ century historical palace to fulfil this kind of functions on the basis of the social welfare home in Krzesimów.

\subsection{Historical outline of Krzesimów}

This area was entered into the register of monuments ,as the example of the spatial layout from the $19^{\text {th }}$ century on the basis of the original complex, of well preserved composition and stand, of historical, esthetical, natural and ecological value." [6]. The palace-park complex in Krzesimów comprising the historical ponds is situated on the hill bordering from the west with a river. The first records of Krzesimów date back to 1409 . Well-preserved $19^{\text {th }}$ century palace was erected by the former owners of the lands, the Stamirowski family. The palace is two-storey, brick building in the classicist style (Fig. 1). The complex consists of an annex (which was built in the first half of the $19^{\text {th }}$ century just like the palace) and such buildings as labourer quarters, two barns, a garner and a hops drying room.

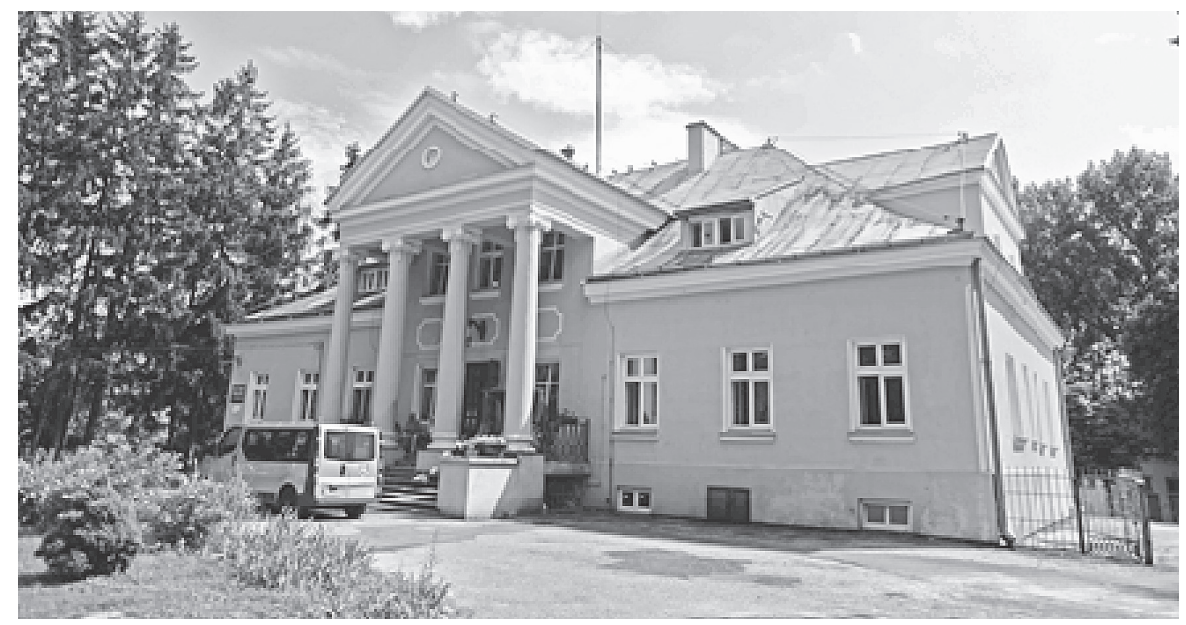

Fig. 1. The front façade of the palace in Krzesimów (Photo: the author)

Over the time, the palace in Krzesimów was adapted many times to new functions, but it has never undergone the complete overhaul. Characteristic elements of historical park complex have been gradually worn-away (e.g. the fish pond on the western side of the palace which was closed). Just like most historical buildings in Poland, the complex in Krzesimów was exposed to the destroying effects of the war. At the end of World War II, a central work camp was created in Krzesimów. The prisoners were living in the old farm buildings and the palace was the headquarters of one of the units of the Ministry for Public Security. Since 1970s, the classicist park complex with the buildings has been used by a social welfare home. In 1997 - 98, the annex building was renovated. The ground floor and attic were adapted to residential function [6]. 


\section{The problems regarding the adaptation of the historical buildings}

The problems regarding the adaptation of the historical buildings arise already at the stage of the selection of their function. It's most usually the owner who has the biggest impact on the decision how the building will be used. An architect is responsible only for adaptation of the building to serve this function in the most suitable manner. Properly performed adaptation should make good conditions to pursue the assumptions of the functional program while respecting the historical fabric of the building [7]. However, the experiences and lessons drawn from the observations of completed realisations concerning design of the historical buildings in Poland and abroad, shows that it might be really problematic to realise these two assumptions at the same time. In some cases, the need to preserve historical elements enforces the modification of the design, which might decrease its functional efficiency.

The main functional problem observed in the analyses of the buildings' adaptation for the purposes discussed hereby is alteration of its function to serve the needs of the people with reduced mobility. There is no univocal definition of the disabled person. There are different types of disability (motor disability, impaired hearing or eyesight, etc.). That is why for this kind of projects, it is assumed that the space shall be designed to meet all the requirements of the person moving in the wheelchair. Such aspects as for example the physical range of arms and legs, the difference of the seat height or manoeuvrability of the wheelchair are taken into consideration. Other important problem is to adapt all passages and access ways to provide unhindered mobility for wheelchair users in the building [8].

The historical buildings are unique in the domain of renovation because they have imposed individual requirements concerning their preservation; therefore, they can't be adapted freely to the requirements of the public buildings. The adaptation of a historical building to fulfil the new (current) purpose is very common but usually problematic issue. One of the difficulties during the phase of design that aims at preparation of the space to fulfil a new function is limited space. According to Assoc. Prof. Piotr Molski PhD. Eng., the design in this case covers such aspects as:

- Modernisation of technical equipment;

- Change of used or damaged construction elements or whole construction parts of a building;

- Transformation of functional layout and division of the interiors;

- Implementation of a cubature in complexes and buildings partially preserved (parahistorical implementations);

- Addition of a cubature and development elements (ahistorical implementations) [9].

The functional layout of a historical building should decide on its functional capability [7]. However, most often it is completely opposite, which then impacts the aesthetics of the adapted building. The possibilities and range of modifications concerning adaptation depends above all on the characteristics of a building and its spatial scale. Indispensible building's technical conditions surveys of are also crucial in this case.

\section{The former functional and spatial modifications in Krzesimów}

Today, the functional layout of the palace in Krzesimów differs substantially from the original internal division. A common feature of the spatial organization of the grand architecture buildings from Renaissance to Classicism period was enfilade, i.e. a suite of rooms aligned with each other, where each door faces other door leading to an adjacent room. Such 
connection system was used also in the discussed palace, but over the time and due to changing regulations concerning the social welfare homes, it was necessary to adapt the building to a new way of use and to introduce substantial modifications. The schemas below present preserved, original wall configuration marked with black colour and the secondary division of the rooms in the palace marked with hatching designed to improve the comfort of the residents of the building. (Fig. 2).

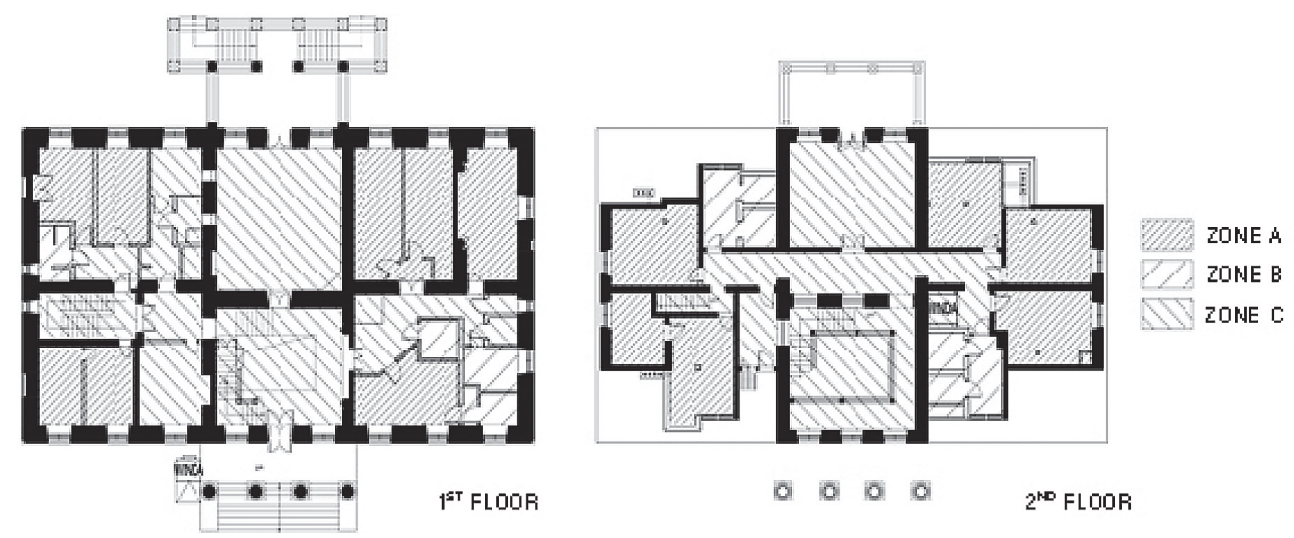

Fig. 2. The scheme of division into the functional zones (own elaboration)

Zone A (strefa A) shows accommodation spaces divided according to the conditions defined in the Regulations of the Minister for Labour and Social Policy on the social welfare homes [1] with special reference to minimum surface, which needs to be provided for a certain number of residents of a room. The building has single, double and triple bedrooms, whereas the adjacent annex has rooms for four persons. Zone B (strefa B) indicates sanitary facilities designed to meet the requirements of people with reduced mobility and wheelchairs users. Toilets are equipped with rails and handles, which facilitate e.g. moving between a wheelchair and a toilet or shower, or moving close to the sink. Separate shower cabins are equipped with shower seats for elderly people and those with reduced mobility. Zone C (strefa $\mathrm{C}$ ) is the space comprising kitchen distribution room with utility elevator near the canteen, the duty office, the smoking room and the communication room. This zone might be defined as service space. Underground floors, the first and the second level of the basements are functionally also the part of the zone C. Despite the modest modification of the wall configuration, the need to fit kitchen, boiler house, laundry room and storage and technical facilities in the available space made it essential to do renovation works to make ventilation system in order to provide good sanitary conditions. The second floor was adapted mainly for the needs of the zone A. In order to get the required space for bedrooms, it was necessary to modify the configuration of the knee walls based on lightweight construction. The toilets on this floor are also equipped for the needs of the persons with disabilities. The first and second floors are connected with two staircases, which were constructed with the original palace, and with the modern elevator (Fig. 3). In order to improve living conditions, each bedroom was equipped with natural ventilation system (Fig. 4). Ventilation grills were connected with designed chimney with the use of elastic cables. Due to that, the additional elements have appeared on the façade of the palace. It was significant but necessary interference in the outside form of the building. 
Within the frameworks of the adaptation of the building to the needs of a social welfare home, the minor changes were also introduced. Mechanical ventilation devices on underground floor were put in the kitchen and laundry windows and under the terrace from the side of the garden (Fig. 4). Another secondary element is the elevator beside the main entrance, which facilitates the mobility of the wheelchairs users (Fig. 4). The palace in Krzesimów, among the many other historical buildings, was one the examples of the situation where introduction of spatial and functional changes was inevitable to fulfil its designated function. The basic design problem, which had to be solved taking into consideration numerous factors and regulations, was to adapt historical elements to meet the requirements of the patients with various types and level of disability.

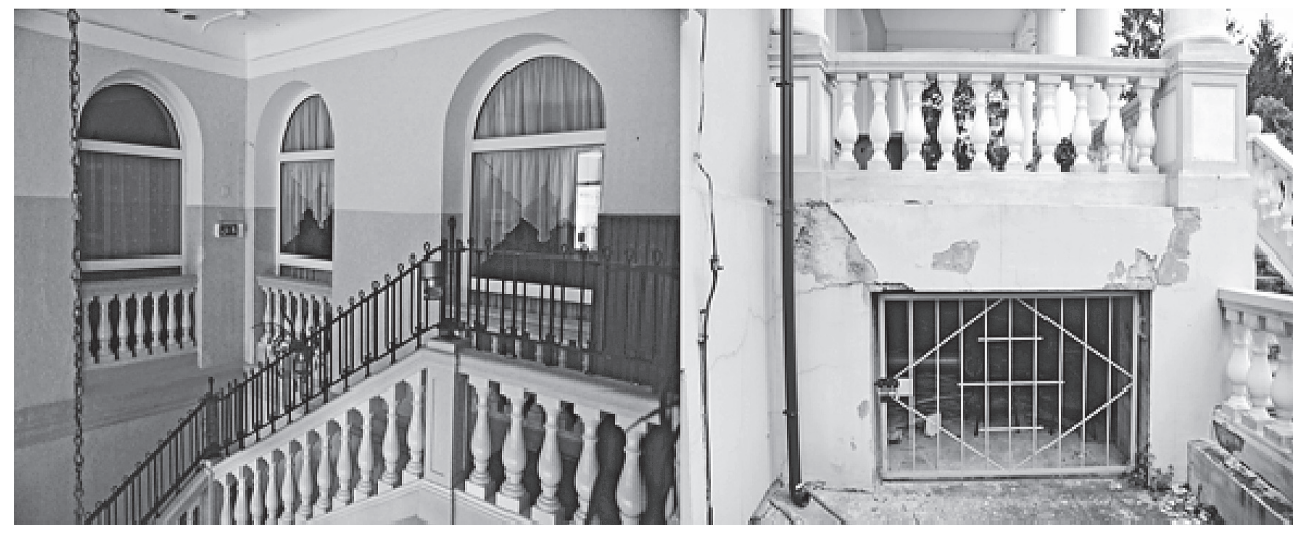

Fig. 3. The security features on the staircases and the space under the stairs to terrace from the side of the garden. (Photo: the author)
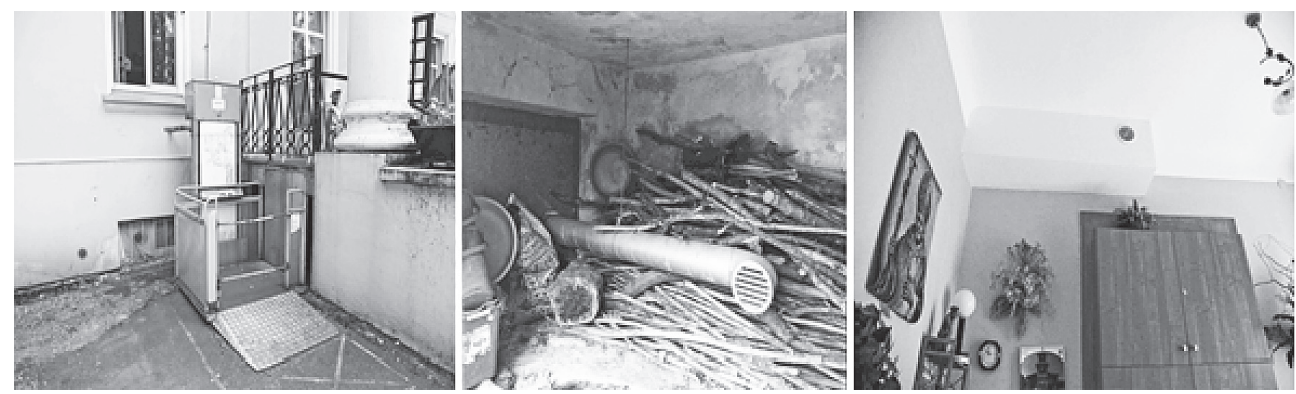

Fig. 4. The secondary solutions aimed at improvement of living conditions and functionality of the building. From left: the elevator beside the main entrance, mechanical installation under the terrace of the garden, ventilation grill inside the building. (Photo: the author)

\section{Conclusions}

\subsection{The problems of the building}

In March/April 2016, a technical condition survey of the palace of Krzesimów was conducted [10]. On the basis of this report, it is necessary to apply conclusions and indications 
described in this chapter. The analysis takes into consideration the wide range of indications described and justified by the authors. It aims at improvement of the state of the building. By preparation of the plan of renovation, one should develop and anticipate the works to improve above all the condition of the foundations, the foundation walls and the roofing. Should the need arise to make thermal modernisation of the building (and if this need is supported with the calculations), it is necessary to use isolation materials inside the building keeping the historical architectural appearance of the space (mainly staircase and canteen). This solution will bring the expected results from the point of view of thermal efficiency, but it will affect adversely useful floor area of the rooms used by the residents. The Regulation of the Minister for Labour and Social Policy of 23 $3^{\text {rd }}$ August 2012 on social welfare homes defines required surface of the rooms and the way and extent they are equipped with furniture. Introduced changes and conducted construction works may contribute to the modification of functional parameters of the rooms, which might result in the situation where regulations currently in force won't be fulfilled. In case of all design and renovation works, it is necessary to thoroughly analyse and consider the conditions and decisions of Voivodship Conservator of Monuments and the applicable regulations on the designing of such facilities.

\subsection{Proposed solutions}

The Palace in Krzesimów currently hosts social welfare home, and that means that it was adapted to fulfil the needs of elderly people and people with various types and levels of disability according to the requirements included in the Regulation of the relevant Minister. However, on the basis of the conducted survey and on-the-spot inspection, we should underline that for the future renovation it is necessary to consider additional solutions facilitating the use and improving the comfort of residents already at the design stage. One of the most important thing that needs to be considered before start of the future investment is equipment of the residential rooms with mechanical ventilation and the canteen and dayroom with air conditioner. It should be designed in a way that has the least impact on the historical fabric. Other solutions, which need to be implemented, concern aesthetical and technological issues to a substantially lesser extent. It is worth mentioning that in the design process one should not take into consideration disability understood only as limited mobility, but also as impairment of other senses like sight and hearing. In order to adapt the building to the needs of people with various disabilities, it is necessary to choose special system of colours, illuminations, alarms and sound signals to improve the accessibility and quality of the use of the building both by the residents and by the caregivers.

\section{References}

[1] Dz.U. 2004 No. 64 item 593 (Polish Journal of Laws).

[2] Szluz B. Dom pomocy społecznej jako forma wsparcia nad osobami starszymi, Elan Vital v Priestore Medzigeneračných Vzt’ahov, Zborník príspevkov z konferencie s medzinárodnou účast'ou 2010, 284-290.

[3] Zych A. Dom pomocy społecznej. [w:] Elementarne pojęcia pedagogiki społecznej i pracy socjalnej, Eds.: Lalak D., Pilch. T. Warszawa: Żak, 1999, 61.

[4] Niedbalski J. Między kontrola a autonomia - instytucjonalne uwarunkowania życia niepetnosprawnych intelektualnie mieszkańców domu pomocy spolecznej. w: Niepelnosprawność $-z a-$ gadnienia, problemy, rozwiazania. Nr IV/2013(9), 47-64. 
[5] Tarkowska E. Życie codzienne w domach opieki społecznej, Warszawa, Wydawnictwo Instytutu Filozofii i Socjologii PAN, 1994, 135.

[6] Wytyczne konserwatorskie do planowanego remontu budynków i rewaloryzacji parku. Krzesimów, gm. Mełgiew - the palace-park complex was entered to the register of monuments of Lublin Voivodeship under the no. A/740, on the basis of the decision of 15 September 1977, sign: KL.IV - 7/26/77.

[7] Czyżniewska J. Uwagi dotyczace problemów adaptacji obiektów zabytkowych do wspótczesnej funkcji, [w:] Adaptacja obiektów zabytkowych do współczesnej funkcji użytkowych, WarszawaLublin 2009, wyd. Politechniki Lubelskiej, 19-28.

[8] Budny J. Dostosowanie budynków użyteczności publicznej - teoria i narzędzia, Warszawa 2009, 6-10.

[9] Molski P. Adaptacja-formy i uwarunkowania [w:] Adaptacja obiektów zabytkowych do wspótczesnej funkcji użytkowych, Warszawa-Lublin 2009, wyd. Politechniki Lubelskiej ISBN 978-837497-085-3, s. 87-98.

[10] Trochonowicz M., Szostak B. Ekspertyza dotyczaca stanu technicznego pałacu i oficyny w Krzesimowie, Fundacja Rozwoju Politechniki Lubelskiej, 2016. 
